\title{
Crop-raiding elephants and conservation implications at Way Kambas National Park, Sumatra, Indonesia
}

\author{
Philip J. Nyhus, Ronald Tilson and Sumianto
}

\begin{abstract}
Crop raiding by wild elephants is one of the most significant sources of park-people conflict in Sumatra, Indonesia. The distribution, impact and conservation implications of elephant crop-raiding in 13 villages that border Way Kambas National Park in southern Sumatra were studied for 18 months. The data are based on rapid village and field assessments, data logs maintained by village observers and a quantitative household survey. Elephants raided crops year-round at a mean rate of 0.53 elephants per day for the entire study area. The frequency of crop raiding was related to vegetation type along the park border, the size and presence of rivers, and the distance to the park's Elephant Training Center (ETC), which houses about 150 captive elephants. Wild elephants damaged at least $450,000 \mathrm{sq} \mathrm{m}$ of corn, rice, cassava, beans and other
\end{abstract}

\section{Introduction}

Conflict between wildlife and people is an important factor affecting the relationship between protected areas and the people who live near them (Studsrod \& Wegge, 1995; Hill, 1998). In Asia, conflict between wild elephants Elephas maximus and people occurs to a varying extent throughout the elephant's range (Seidensticker, 1984; Sukumar, 1989). As human populations increase and elephant populations become more concentrated in isolated protected areas and remnant forest habitats, these conflicts are almost certain to escalate (Santiapillai \& Widodo, 1993b; Stüwe et al., 1998). Understanding the reasons for and potential solutions to these conflicts is necessary to improve relationships between elephant protected areas and residents living adjacent to these areas. Failure to do so will lead to further hostility and increase the probability that elephant populations will continue to decline.

Philip J. Nyhus (corresponding author) Institute for Environmental Studies, 70 Science Hall, University of Wisconsin, Madison, W1 53706, USA. Current address: Colby College, Waterville, ME 04901, USA. Tel.: + 1207872 3763; fax: + 1207872 3731; e-mail: pjnyhus@colby.edu.

Ronald Tilson and Sumianto Sumatran Tiger Project and Minnesota Zoo, 13000 Zoo Blvd., Apple Valley, MN 55124, USA.

Revised manuscript accepted for publication 20 May 2000 annual crops, and close to 900 coconut, banana and other perennial trees in the area surveyed. Elephants killed or injured 24 people over a 12-year period in villages near the park. Villagers try to reduce elephant damage by guarding fields, digging trenches between the park and their fields, and modifying their cropping patterns. Elephant-human conflict decreases the probability of support from local people for conservation efforts. We suggest methods to improve the effectiveness of existing elephant trenches, the need to consider electric fences, external support to affected villages, and compensation to villagers for any damage caused.

Keywords Crop raiding, elephant, human-wildlife conflict, Sumatra, Way Kambas National Park.

Complaints from communities that are subject to regular crop depredation are frequently noted by protected area managers, but detailed assessments of crop damage are rarely made or testable hypotheses developed to predict damage because of the complexity of the factors responsible (Naughton-Treves, 1998). Despite the ubiquity of elephant-human conflict and the relatively high cost of various elephant control strategies now employed, few studies have analysed the reasons for their success or failure, or the impact of different protected area boundary and land-use types adjacent to elephant habitat on crop raiding (Seidensticker, 1984; Sukumar, 1989; Newmark et al., 1994; Thouless \& Sakwa, 1995; Hill, 1998; Naughton-Treves, 1998).

This is particularly true on the island of Sumatra, Indonesia, the only home of the Sumatran elephant $E$. m. sumatranus (Santiapillai \& Jackson, 1990). Much of what is known about the status of elephants in Sumatra and elephant-human conflict is summarized in Tilson et al. (1994). Detailed population estimates are unavailable, but the total elephant population on Sumatra is estimated at between 2800 and 4800 , discontinuously distributed across Sumatra (Blouch \& Haryanto, 1984; Blouch \& Simbolon, 1985; Santiapillai \& Jackson, 1990). Out of 47 identified populations, only 38 are sufficiently large to be considered viable (Tilson et al., 1994). Elephants have been considered threatened and officially 
protected in Indonesia since 1931 (Senanayake \& Kusumawardhani, 1986). The provinces of Riau, Aceh and Lampung contain most of Sumatra's elephants (Santiapillai \& Jackson, 1990; Tilson et al., 1994).

No accurate estimates of elephant populations exist for Way Kambas National Park. Early estimates ranged from 30 to 50 animals, but more recent estimates range from 250 to 350 animals (Blouch \& Haryanto, 1984; Santiapillai \& Suprahman, 1985, 1986; Widjaja et al., 1986; Tilson et al., 1994). Accurate estimates are difficult to make because of the area's dense forest cover (Nash \& Nash, 1986; Salter, 1986; Santiapillai \& Suprahman, 1986; Tilson et al., 1994). Way Kambas was identified as a site to help reduce elephant-human conflict by accommodating displaced herds from neighbouring areas (Widjaja et al., 1986; Ministry of Forestry, 1995). In 1984-85, c. 70 elephants were moved in a major military operation (Operasi Ganesa) from the Gunung Madu sugar cane plantations to Way Kambas (Santiapillai \& Suprahman, 1985). The park is the site of Indonesia's first Elephant Training Center (ETC), established in 1985 and home to c. 150 captive elephants (Krishnamurthy, 1991; Ministry of Forestry, 1995).

Conflict between elephants and people is widespread across the island and media reports about this conflict are frequent and negative (Santiapillai \& Widodo, 1993a,b). In Lampung Province, at the southern tip of Sumatra, a combination of lowland dipterocarp forests, grasslands and abundant forest edge habitat provides some excellent elephant habitat and also some of the most difficult elephant management problems (Blouch \& Haryanto, 1984). Little quantitative information is available about the frequency, distribution, and temporal and spatial patterns of crop raiding by elephants in these areas or about the impact on local people.

The Indonesian Government recognizes the significance of elephant-human conflict and has identified as urgent the need for studies to characterize this relationship in order to develop strategies to resolve elephant-human conflict and to increase public awareness about the importance of conserving wild elephants (Santiapillai \& Jackson, 1990; Tilson et al., 1994). Way Kambas National Park in Lampung Province has long been regarded as a high priority area for elephant conservation and as a 'hot spot' for elephant-human conflict (Santiapillai \& Suprahman, 1986; Santiapillai \& Jackson, 1990; PHPA, 1994; Ministry of Forestry, 1995). The park represents in many ways a vision of the future of elephants in Sumatra and a good part of South-east Asia. As the human population grows and forest conversion and degradation continue to reduce and fragment suitable habitat across the island, it is likely that small, isolated protected areas like Way Kambas will become more common (Nyhus et al., 1999).

The primary aim of this study is to provide a more predictive explanation of crop raiding to help conservation authorities and local people to reduce elephant conflict in the short term, and promote better parkpeople relationships in the long term. We use quantitative and qualitative data to characterize the nature of elephant-human conflict at Way Kambas, and discuss the impacts of elephant-human conflict on local people's attitudes and the effectiveness of current elephant protection strategies. We conclude by arguing the critical importance of vigorously addressing elephant-human conflict to reduce the risk of losing support among people living near protected areas like Way Kambas for the conservation of elephants and other endangered animals and plants that share the elephant's habitat. Without sufficient information to develop realistic programmes to reduce humanwildlife conflict in Sumatra's last forests, the future of some of Asia's most magnificent animals will be less secure.

\section{Study area}

Way Kambas National Park, a $1300-\mathrm{sq}-\mathrm{km}$ degraded lowland tropical forest, is located along the east coast of Lampung Province in southern Sumatra (for description, see Nyhus, 1999) (Fig. 1). It provides favourable habitat for Asian elephants (Santiapillai \& Suprahman, 1986).

Small-scale cultivation is the predominant livelihood strategy near the park. The primary annual food crops cultivated include irrigated and rain-fed rice Oryza sativa, corn Zea mays, cassava Manihot esculenta, and a variety of vegetables and legumes. Rice is the preferred staple food crop but cultivation is often irrigation-dependent. Perennial crops include coconut Cocus nucifera, banana Musa spp., coffee Coffea spp., and other fruit and spice trees. Agricultural fields are generally located near, but spatially separate from, the primary village area. Most farmers cultivate two major crops each year, and sometimes three if they have access to irrigation. Farmers plant and harvest crops on variable dates within the wet and dry seasons, creating a patchwork of different crops at different stages of growth.

\section{Methods}

This study includes 18 months of field data collected from May 1996 to October 1997. Data were collected using three methods: rapid village and field 
assessments in 20 villages, wildlife conflict data $\operatorname{logs}$ maintained by village observers in 13 villages, and a quantitative household survey of 462 households distributed among six villages.

Rapid assessments were carried out using focus groups, semi-structured questions, field visits to areas of elephant damage, and reconnaissance into the forest with villagers to observe habitat types. Night visits were made to observe how farmers guarded their fields and chased elephants.

We developed a technique to assess elephant damage in which local villagers, with their knowledge and daily presence on the 'front lines', were used as informants to record the elephants they observed entering villages and the results of elephant crop raiding. We identified 20 informants in 13 villages previously highlighted in the rapid assessments as having problems with elephants. This study includes every village along the southern border of the park and the three largest villages along the south-west border, representing c. $63 \mathrm{~km}$ or almost 50 percent of the park's non-sea border and c. 90 per cent of the border where villagers report frequent elephant problems. Each assistant maintained daily records of crop raiding by elephants. Standardized forms, collected approximately every 2-4 weeks, were used to record the date, type of animals, number of animals, number with tusks (in Sumatra, only male elephants have tusks), outstanding characteristics of individual animals, the time and location animals entered and left the area, the type and amount of damage to crops, and comments. Periodic field checks were carried out to control for data accuracy.

We carried out a survey with 92 questions about basic household and respondent socio-economic and demographic data, knowledge and attitudes towards wildlife, forest resource use, and information about human-wildlife conflicts. The survey was conducted using a stratified systematic sample of 9 per cent of the 5046 households in six of the participating villages. In this study we summarize the results of elephant-related questions only.

We define the movement of one or more elephants across the park boundary and into cultivated areas for at least $1 \mathrm{~h}$ as an elephant event. Crop damage was not a prerequisite, although informants reported that they sometimes did not record an elephant event if one or more elephants just 'passed through' the village fields without causing damage. The mean number of elephant events is defined as the total number of elephant events divided by the total number of observer days of data. The mean is used instead of the total number of elephant events to account for variations in the number of missing days among observers. We measured crop damage in square metres and damage to perennials in number of trees or stalks. Data were analysed using SPSS (1999), applying analysis of variance, bivariate correlation and the non-parametric Kruskal-Wallis and chi-square statistic when data failed to meet assumptions of normality and equal variance. Vegetation type and distances were derived from a Landsat Thematic Mapper satellite image of the area from 1 August 1996, with Erdas Imagine image analysis software and imported into ArcView GIS v 3.0a.

\section{Results}

\section{Frequency, group size and time}

During the 549-day duration of the study period, 4723 elephants were recorded raiding crops on 1301 separate occasions in the 13 villages where conflict data logs

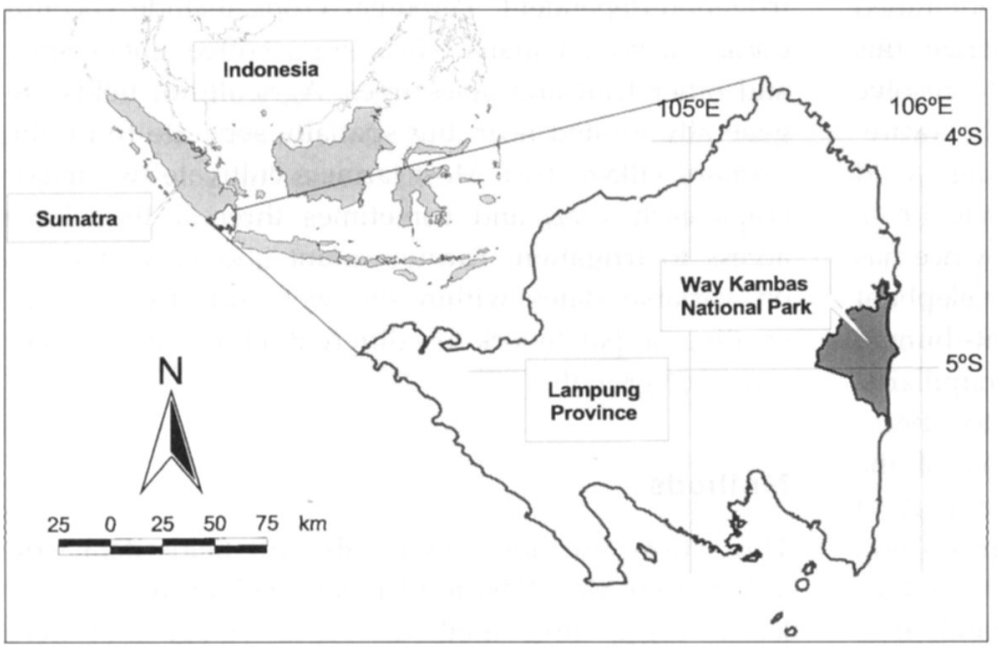

Fig. 1 Location of Way Kambas National Park, Lampung Province, Sumatra, Indonesia. 


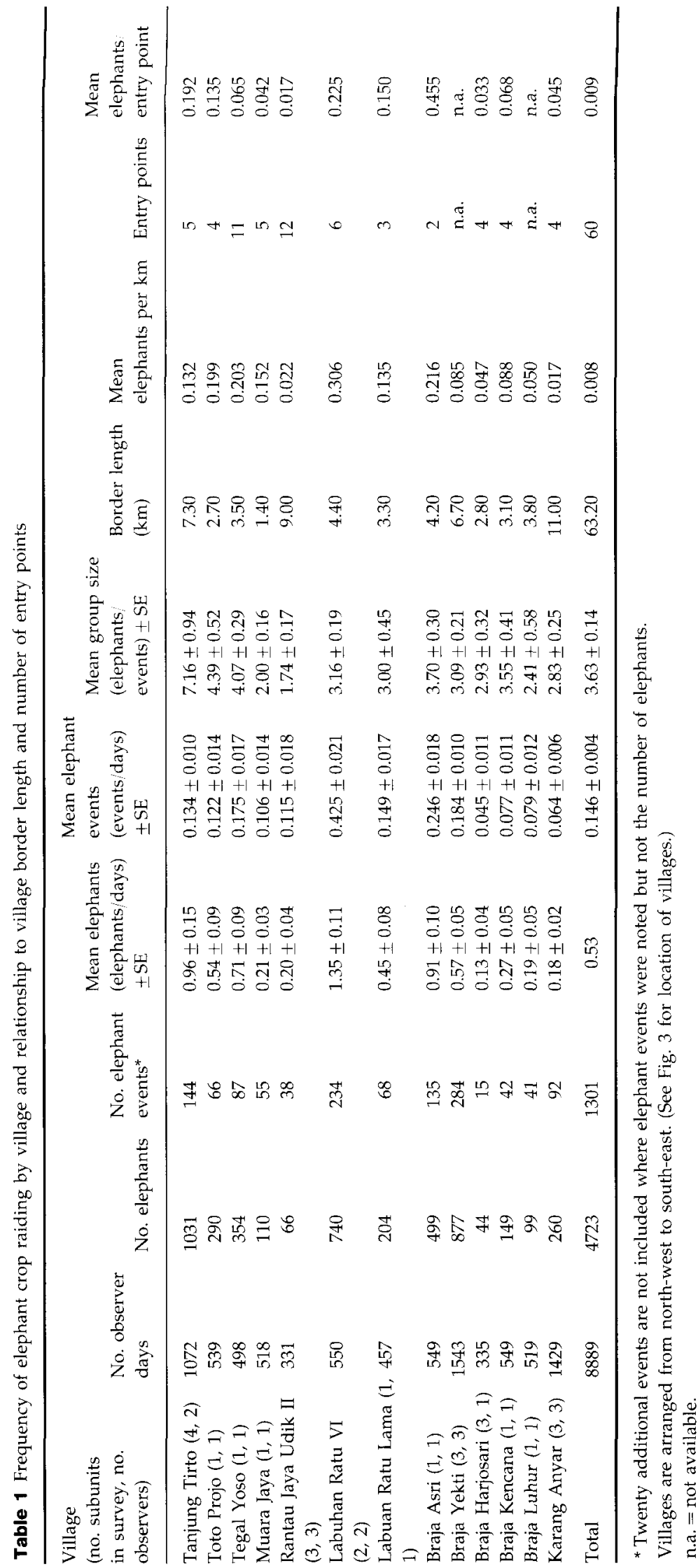




\begin{tabular}{llllll}
\hline Category & Elephant events & Mean & Median & Min. & Max. \\
\hline Elephant group size & 1301 & $3.63 \pm 0.14$ & 2 & 1 & 50 \\
Time entered fields (h:min) & 1301 & $17: 00$ & $20: 00$ & n.a. & n.a. \\
Time left fields (h:min) & 1069 & $09: 48$ & $04: 00$ & n.a. & n.a. \\
Total time in fields (h:min) & 1044 & $06: 29$ & $06: 00$ & $0: 01$ & $23: 35$ \\
\hline
\end{tabular}

Table 2 Summary statistics for elephant group size, the time elephants entered and left fields, and the total time elephants spent outside the park boundary before returning to the park

n.a. $=$ not available

were maintained. Adjusting for dates where no information was collected, a mean of $0.53 \pm 0.024 \mathrm{SE}$ elephants per day (total elephants/total days) or 0.08 elephants per day per $10 \mathrm{~km}$ of park boundary raided crops in the study area (Table 1).
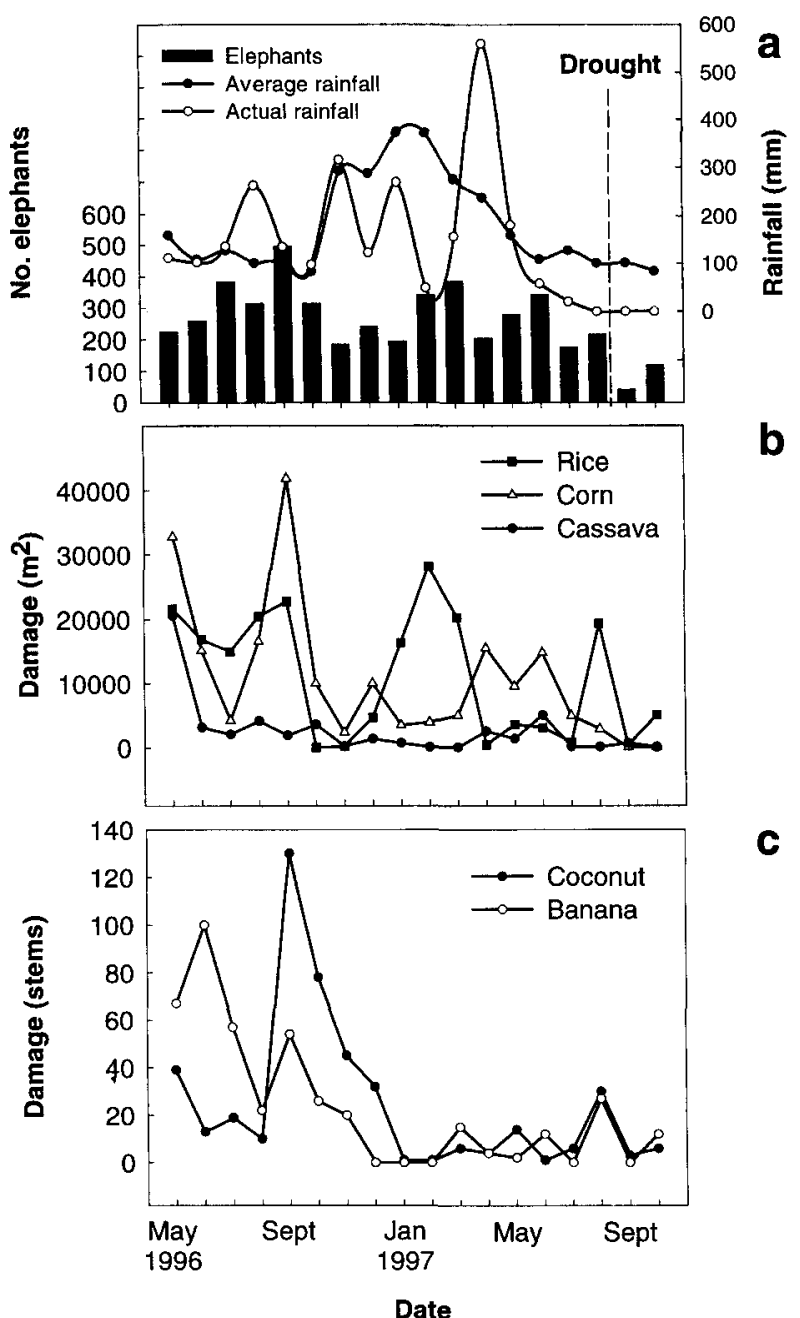

Fig. 2 Total number of elephants, 10-year average monthly rainfall, and actual monthly rainfall (data from local government irrigation office) over the study period (a). Severe drought began in July 1997. Total damage to primary annual crops (b) and perennial crops (c).
Mean elephant group size was $3.63 \pm 0.14$ and 966 (74.3 per cent) elephant events had groups of three or fewer elephants (Table 2). In 547 incidents in which elephants with tusks (males) were identified, almost half (48.6 per cent) were single individuals, and another onethird ( 30.5 per cent) were in pairs. The majority ( 81.4 per cent) of elephants entered farmers' fields between 19:00 and 24:00 $\mathrm{h}$ with a median time of 20:00 $\mathrm{h}$. The median time elephants left farmers' fields was 04:00 $\mathrm{h}$. Elephants were in village fields on average $6.29 \mathrm{~h}$ (median $=6 \mathrm{~h}$ ) per event (Table 2).

\section{Crops damaged}

Elephants reportedly damaged at least $450,000 \mathrm{sq} \mathrm{m}$ (45 ha) of rice, corn, ground beans and cassava. Damage differed significantly by month for both annual crops (Kruskal-Wallis chi-square $=28.32, \mathrm{df}=11, P=0.003$ ) and perennial tree crops (chi-square $=59.95, \mathrm{df}=11$, $P<0.000$ ). The most striking observation is that elephants entered village fields and damaged crops year-round (Fig. 2). Rice (193,084 sq m) and corn $(198,941 \mathrm{sq} \mathrm{m})$ were the annual crops damaged most. Figure 2a shows the number of elephants entering village fields and the average and actual rainfall for each month. Rainfall helps to determine when crops are planted and harvested. Damage to rice and corn tended to increase at the transitions between wet and dry seasons (AprilMay or August-September), approximately coinciding with the harvest of the wet season and dry season crops (Fig. 2b). Damage to rice was also greatest during the wet season when rain-fed rice is commonly grown. Cassava damage occurred year-round and showed little variation except during the month of May 1996. At least 870 trees were damaged, almost all of which were coconut trees (438, 50.3 per cent) or banana trees $(418,48$ per cent). Damage to coconut and banana trees was greatest in May-June 1996 and September-October 1996 (Fig. 2c). Damage to all crops was low during the months of September and October 1997, coinciding with the beginning of a major El Niño Southern Oscillation (ENSO) drought event. Few farmers cultivated crops during this period. 
Fig. 3 Distribution and frequency of crop raiding by elephants at Way Kambas National Park. Crop raiding was less common where rivers are wide and wetlands numerous $(a, f)$ or open scrub and grassland

vegetation is common (c). Crop raiding was more common where forest (d) or scrub vegetation (b, e) was located adjacent to the park border.

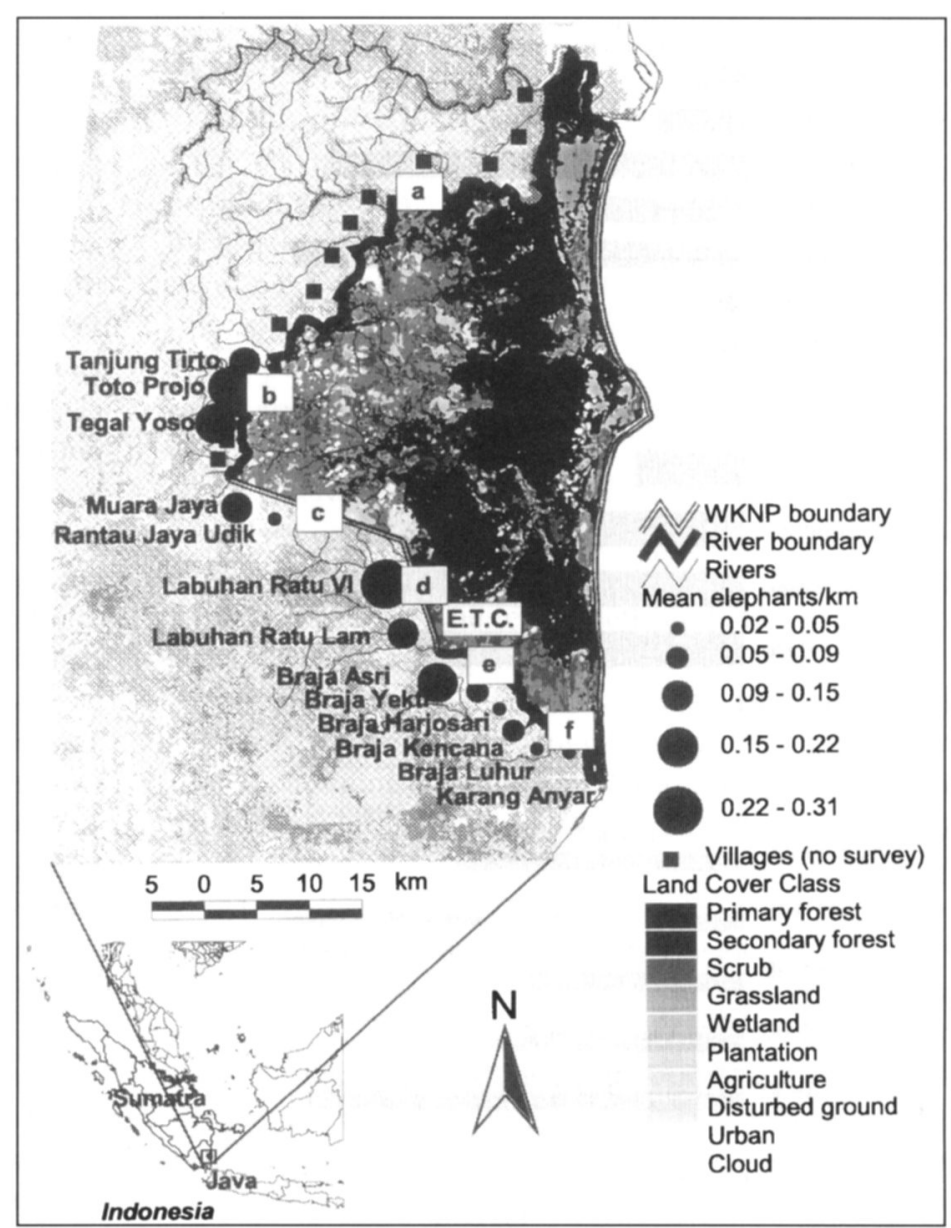

where the rapid assessments found infrequent or no elephant crop raiding.

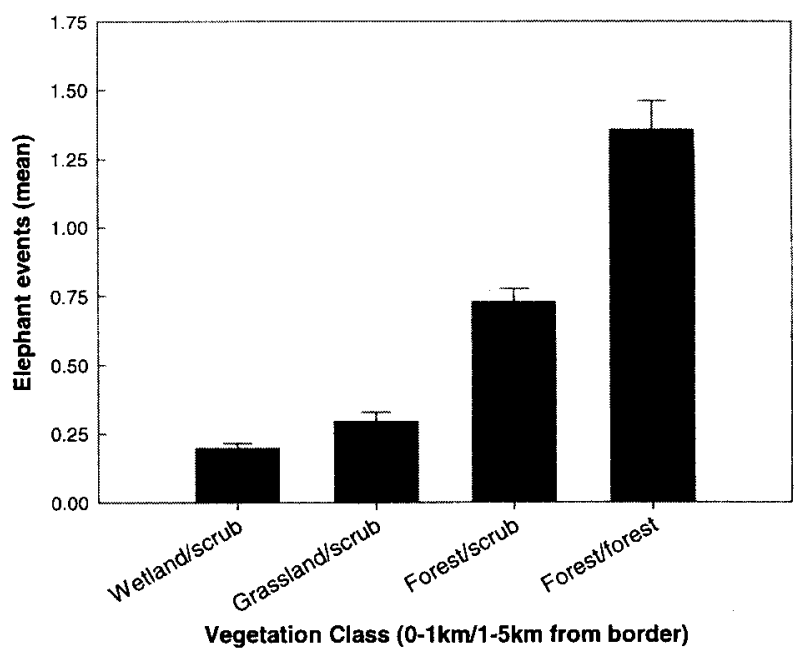

Fig. 4 Relationship of mean elephant damage to qualitative vegetation categories adjacent to the park border and c. $0-1$ and $1-5 \mathrm{~km}$ from the park border. 


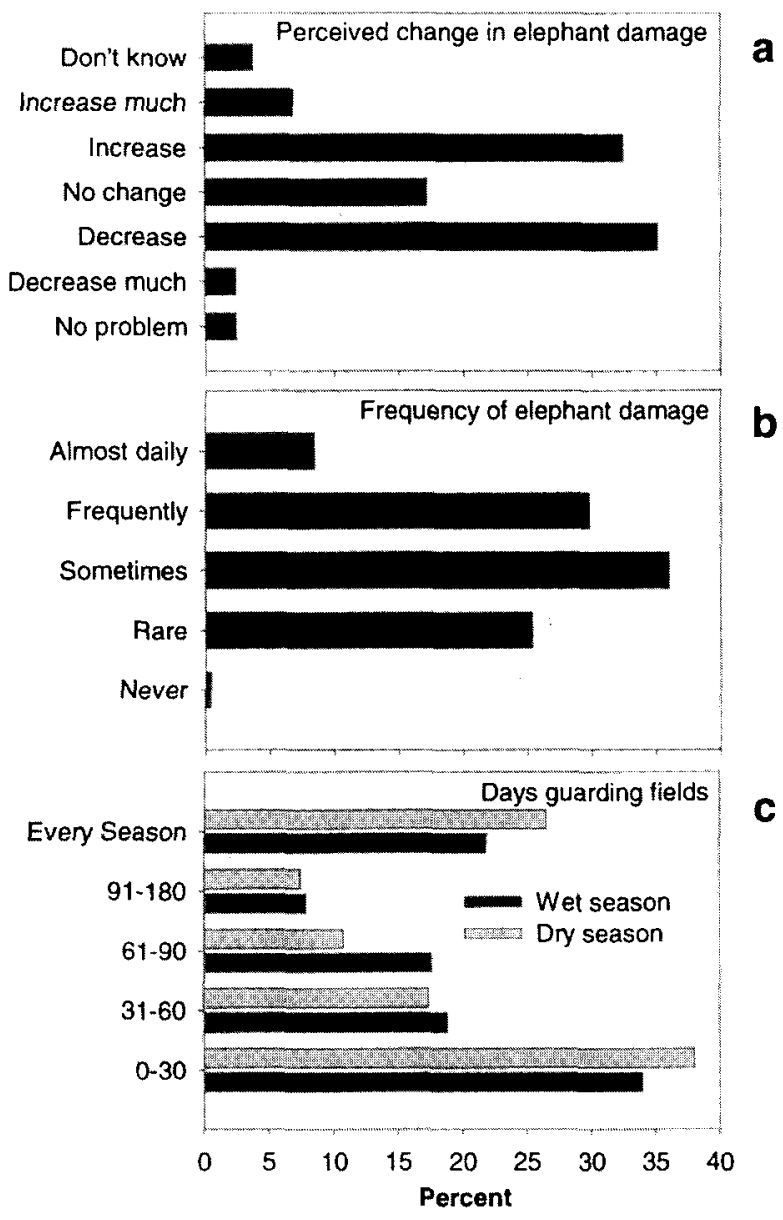

Fig. 5 Perceived change in elephant damage $(n=457)$ (a), frequency of elephant damage $(n=225)(b)$, and number of days guarding fields from elephants $(n=121-165)$ (c) among respondents in the household survey.

We characterized vegetation along the park's border into four qualitative categories from high to low percentage of tree cover (forest, scrub forest, grassland and wetland) to evaluate whether vegetation was related to the number of elephant events. The mean number of elephant events increased significantly with greater tree cover among vegetation categories (chi-square $=510.9$, $\mathrm{df}=3, P<0.000$ ) (Figs 3 and 4). Wide, open areas tended to have the fewest elephant events; dense, covered areas tended to have the most elephant events.

According to reports from villagers, elephant-human conflict was rare in villages near the park from 1950 to 1980. During the rapid assessment survey, villagers were asked in what year(s) conflicts became more common in their village. Thirteen villages provided specific dates: five identified 1986, three identified 1980, and the remaining five identified a year between 1982 and 1985 as the year conflict increased in their village. This coincided with the designation of Way Kambas as a proposed national park in 1978 and the translocation of c. 70 elephants into the park in 1984-85.

\section{Impact and control of elephant-human conflict}

At least 15 people were reportedly killed and 9 injured in 11 different villages near the park between 1984 and 1996, an average of almost one death and one injury a year. Respondents also described five cases where elephants were killed near Way Kambas. In one incident, elephants stuck in a trench were burned by villagers, in the others elephants were poisoned.

To determine the extent that conflict was a concern among local villagers, people were asked a series of questions about elephants and elephant conflict. Over half the respondents (257, 56.4 per cent) believed the elephant problem was stable or increasing (Fig. 5a). Two hundred and twenty-seven (49.7 per cent) respondents reported crop damage by elephants in the last year, and 86 (38.2 per cent) perceived damage to occur frequently or almost daily (Fig. 5b). One hundred and eighty-three (39.6 per cent) of all respondents who answered the question, 'Do you guard your crops from elephants?', responded positively. Of those that guarded their fields, about half guarded them for up to 1 month each planting season and a quarter guarded them for between 2 and 4 months each planting season (Fig. 5c).

Strategies used by farmers to reduce crop raiding by elephants range from individual and household efforts to those that require community participation or outside support. Guarding their fields is one of the most prevalent methods. Huts or watchtowers are constructed along the park boundary where elephants frequently enter village fields. When elephants are spotted, villagers use a combination of loud noises, including yelling, firecrackers, hitting metal objects and cracking whips. Bright lights, including flaming torches and powerful flashlights, are also used. Direct contact with elephants is less common, but objects are thrown and some villagers move close enough to use whips. These methods reportedly have become less effective over time.

Communally, farmers report that they often plant crops at the same time as other farmers so that they can share the time-consuming task of watching their fields. Farmers occasionally report harvesting crops before they are fully mature or planting less valuable crops to avoid the risk of catastrophic damage in the final days before harvest. Trenches are used along virtually the entire extent of the land border of the park. Measuring c. $2 \mathrm{~m}$ wide by $3 \mathrm{~m}$ deep, they are dug by an excavator. Soils high in clay, vegetative ground cover and periodic maintenance by villagers enable these trenches to remain intact in many areas. Only where small rivers, 
streams or wetlands cross these trenches is their effectiveness reduced. Elephants avoid areas where the trenches are well-kept and intact, but where water flows, the trenches are eroded or cannot be constructed and elephants pass freely through these openings.

When asked what methods they thought were necessary to reduce elephant crop raiding, 68 per cent of 488 respondents in the household survey replied that guarding their fields and chasing or scaring elephants using fire, noise or lights would be the most effective. Twenty-five per cent cited structural barriers, including trenches, electric fences or deepening rivers, and the remainder cited government assistance and elephant translocations as effective control measures.

\section{Discussion}

\section{Distribution and patterns of crop raiding}

This study shows that crop raiding by elephants is a significant and growing problem in more than half of the 27 villages adjacent to Way Kambas National Park. Physical and biological features appear to explain much of the distribution in crop raiding (Fig. 3). Elephant crop raiding was least common where rivers are widest. Few or no elephant events were reported north of Tanjung Tirto (a), the confluence of the Sukadana and Pegadungan Rivers, the widest river boundary and an area where small fishing boats are common, and in the south-east corner of the park (f) where the Penet River is widest, wetlands are numerous, and the distance to the centre of the park is great.

On average, more elephants entered villages with land boundaries than villages with shallow or narrow

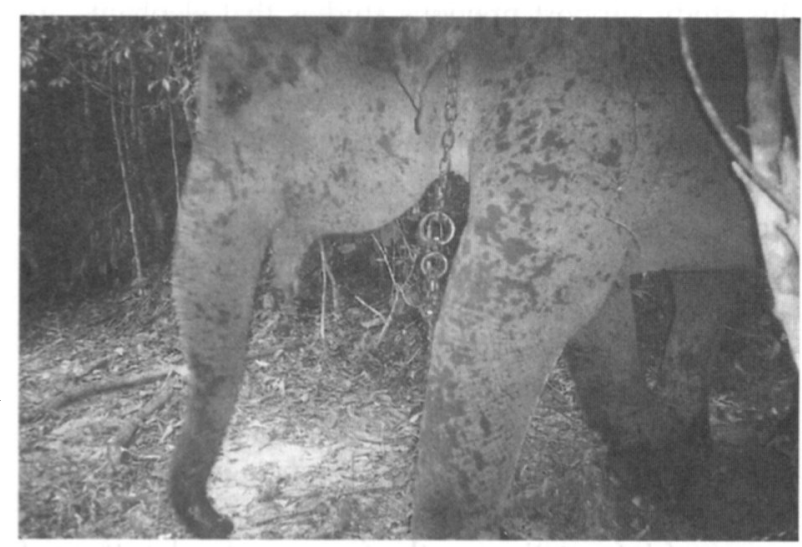

Plate 1 A 'wild' elephant in Way Kambas National Park photographed with an infrared-triggered camera. The chain around its neck suggests the elephant escaped from captivity. (Directorate General of Nature Protection and Conservation, Ministry of Forestry and Estate Crops, Republic of Indonesia, Sumatran Tiger Project, Way Kambas National Park.) rivers. Nevertheless, the relatively low frequency of elephant damage along land boundaries suggests that the elephant trenches, while imperfect, have the potential to help reduce the number of elephants entering these villages. This is supported by anecdotal evidence from villagers in locations with elephant trenches, who claim the frequency of elephant damage decreased considerably after the trenches were built.

The presence of forest cover adjacent to agricultural areas appears to be a good predictor of heavy crop raiding. The greatest number of elephants left the park where there was dense forest cover adjacent to the boundary or where dense secondary growth forest provided cover between the boundary and surrounding mixed grasslands. The fewest left the park where open wetland or Imperata grassland provided little cover.

Seidensticker (1984) and Santiapillai \& Suprahman (1986) have previously suggested that wide buffer zones containing Imperata grassland or other vegetation that do not offer suitable food or cover for elephants could effectively separate cultivation areas and protected areas. Elephants can, and do, cross large expanses of open area, but in this study, the mean number of elephant events was significantly higher where dense secondary growth forest abuts the park border compared with wetland and grassland areas where few trees are found. Elephants waited for the cover of darkness to enter village fields, and were often seen lining up across the border at sunset.

These patterns fit with the known ecology of Asian elephants: the availability of water, food and cover are three factors that influence the movement of elephants. Water is important because elephants may drink in excess of $200 \mathrm{~L}$ per day, and tend to move along streams, rivers and irrigation canals on a regular basis, especially during dry seasons (McKay, 1973; Seidensticker, 1984; Sukumar, 1989). Elephants are generalist feeders and voracious eaters, consuming between 6 and 8 percent of their body weight each day (Sukumar, 1989). The availability of high nutrition plants in cultivated areas is a major factor explaining why elephants leave the safety of forest areas to raid crops (McKay, 1973; Sukumar, 1989; Santiapillai \& Widodo, 1993b). Elephants frequent the ecotones between forest and grassland to feed on grasses without venturing too far from the shade and relative safety of the forest (McKay, 1973; Santiapillai \& Widodo, 1993b). In Way Kambas, Santiapillai \& Suprahman (1986) previously suggested that the distribution of elephants appeared high in the forest zone and ecotonal area of the park and along the south-central border, a pattern confirmed in this study.

Villagers frequently suggested that the increase in crop-raiding events in the 1980 s coincided with the closing of the park to villagers (early 1980s), the trans- 
Table 3 Possible elephant control methods available for Way Kambas, their relative effectiveness, cost and principal constraints

\begin{tabular}{|c|c|c|c|}
\hline Strategy & Relative effectiveness & Relative cost & Principal constraints \\
\hline Elephant trenches & $\begin{array}{l}\text { High where land dry and soil } \\
\text { firm; low where wetlands and } \\
\text { streams abundant }\end{array}$ & $\begin{array}{l}\text { High initial cost for excavation, } \\
\text { but maintenance (labour) low, } \\
\text { high cost if cement reinforcements } \\
\text { required }\end{array}$ & $\begin{array}{l}\text { Effectiveness declines where wet- } \\
\text { lands or streams erode banks, not } \\
\text { feasible for entire border }\end{array}$ \\
\hline Electric fences & $\begin{array}{l}\text { High if sufficient power, low if } \\
\text { current weak, maintenance poor }\end{array}$ & $\begin{array}{l}\text { High cost for materials, supplies, } \\
\text { power source, and maintenance }\end{array}$ & $\begin{array}{l}\text { Requires frequent maintenance, } \\
\text { power source, possibly not feasible } \\
\text { where flooding common }\end{array}$ \\
\hline Grass buffer & $\begin{array}{l}\text { Moderate: helps patrols to view } \\
\text { elephants from greater distance }\end{array}$ & $\begin{array}{l}\text { Low but risk of wildfires high, } \\
\text { may reduce habitat for forest- } \\
\text { dwelling species }\end{array}$ & $\begin{array}{l}\text { Already present in some areas, ele- } \\
\text { phants can still cross even large } \\
\text { grass buffers, likely to degrade } \\
\text { forest habitat in the park }\end{array}$ \\
\hline $\begin{array}{l}\text { Capture of habitual } \\
\text { crop raiders }\end{array}$ & $\begin{array}{l}\text { Moderate: but not possible to cap- } \\
\text { ture all elephants }\end{array}$ & $\begin{array}{l}\text { Low because already being carried } \\
\text { out at low levels }\end{array}$ & $\begin{array}{l}\text { Disruptive to social groups, hard to } \\
\text { identify key individuals; large } \\
\text { number of elephants that raid } \\
\text { crops, and no place to put them }\end{array}$ \\
\hline Elephant control teams & $\begin{array}{l}\text { Moderate: reduces the need for } \\
\text { villagers to bear the entire burden } \\
\text { of patrolling, good public relations }\end{array}$ & $\begin{array}{l}\text { Low to moderate, depending on } \\
\text { the number of staff and equip- } \\
\text { ment (e.g. vehicles) involved }\end{array}$ & $\begin{array}{l}\text { Need for dedicated staff would } \\
\text { take away limited resources avail- } \\
\text { able for other management needs, } \\
\text { and their presence would be } \\
\text { needed indefinitely }\end{array}$ \\
\hline $\begin{array}{l}\text { Assistance with } \\
\text { guarding }\end{array}$ & $\begin{array}{l}\text { Low: villagers already guard } \\
\text { crops, but would reduce the eco- } \\
\text { nomic hardship to villagers, good } \\
\text { public relations }\end{array}$ & $\begin{array}{l}\text { Moderate cost for small-scale as- } \\
\text { sistance but large if hundreds of } \\
\text { villagers receive assistance. Long } \\
\text { term cost would be high }\end{array}$ & $\begin{array}{l}\text { Materials already in use. Support } \\
\text { would defray costs but not reduce } \\
\text { total number of elephants crossing } \\
\text { border }\end{array}$ \\
\hline Compensation & $\begin{array}{l}\text { Low: but value in reducing eco- } \\
\text { nomic hardship of villagers }\end{array}$ & $\begin{array}{l}\text { Cost would vary dramatically } \\
\text { based on the size of compensation }\end{array}$ & $\begin{array}{l}\text { Difficulty in deciding who is eligi- } \\
\text { ble for compensation (e.g. personal } \\
\text { injury vs. small-scale damage to } \\
\text { crops) }\end{array}$ \\
\hline $\begin{array}{l}\text { Chemical deterrents } \\
\text { (e.g. pepper spray) }\end{array}$ & Untried in Way Kambas & Untried in Way Kambas & $\begin{array}{l}\text { Limited knowledge of effectiveness, } \\
\text { availability and sustainability }\end{array}$ \\
\hline
\end{tabular}

location of elephants to the park (1984-85) and the establishment of the ETC (1985). In this study, crop raiding tended to increase near the ETC, with the exception of villages along the western border of the park. The large number of female elephants at the ETC could be a magnet to wild bull elephants, especially when both are reproductively active. Villagers reported seeing elephants with cut tusks or chains, suggesting some elephants had escaped or been released from the ETC. Center officials admit to the release of at least five elephants (Rusman, Director ETC, pers. comm.), and at least one elephant with chains around its neck has been photographed in the forest (Plate 1).

The frequency of raiding elephants and the amount of crop damage appear to increase during the months when crops are harvested and planted. Crop raiding was roughly related to seasonal rainfall patterns, but a detailed comparison of cropping cycles and elephant events was not possible because of the variability among farmers in the dates they planted and harvested crops, and the variety of crops planted. The results of this study support previous studies that elephants are most likely to enter villages after dark (Santiapillai \& Suprahman, 1986; Senanayake \& Kusumawardhani, 1986; Sukumar, 1989; Mukhtar \& Sumarna, 1994; Naughton-Treves, 1998).

\section{Discussion of methods}

This study suggests a methodology to incorporate local knowledge and participation, yet maintain a level of rigour and repeatability, suitable to comparisons of other human-wildlife conflict hot spots in Sumatra and South-east Asia. Local informants are a cost-effective source of information on the frequency and pattern of crop damage, and enable efficient study of a large area over a long period of time. This also enhances the informant's stake and capacities in management and protection from wildlife conflict. Participatory methods have been shown to encourage the involvement of local 
people in the management and conservation of wildlife (Marks, 1994). This win-win strategy provides benefits to local villagers, and enables researchers to gather long-term data with the help of the people who best understand the elephant problem.

\section{Possible elephant control methods}

In the past, methods to control elephants at Way Kambas have included the construction of electric fences, trenching, the planting of Musa sapientum and Saccarum spontaneum within the park as 'lure' crops, the provision of mineral licks, the capture of habitual crop raiders (Santiapillai \& Suprahman, 1986) and guarding by villagers. We use the results of this study to suggest several strategies that should be considered by conservation authorities in Indonesia to address elephant crop raiding in the future at Way Kambas (Table 3 ). The Sumatran Tiger Project does not make policy or formulate recommendations because it is not within the project's remit. We hope this information will assist conservation managers to evaluate and recommend more specific conservation and policy recommendations.

Electric fences are widely considered the most effective and cost-effective strategy to control elephant cropraiding (Sukumar, 1989; Thouless \& Sakwa, 1995). At Way Kambas, an initial attempt to construct $7 \mathrm{~km}$ of fence failed because the solar-powered electric current was insufficient, bull elephants used their tusks to destroy the fence, and fence posts were not sufficiently strong (Santiapillai \& Suprahman, 1986; Ministry of Forestry, 1995). A stronger fence with higher current and better maintenance could provide one solution to the elephant problem. Frequent flooding, the challenge of maintaining the entire length of fence and the cost of upkeep are possible drawbacks to this strategy.

Trenches are generally not considered to be an effective or cost-efficient strategy because they have a high rate of failure where soil is loose or very wet and elephants can use their feet to push soft soil into trenches (Santiapillai \& Suprahman, 1986; Sukumar, 1989). In contrast, the experience of Way Kambas suggests that trenches, combined with innovative modifications, such as cement barriers where trenches are eroded, can be a cost-effective and efficient deterrent. In the almost 5 years since the trenches were constructed along the southern border of the park, they have required minimal maintenance, sustained their shape and have retained their effectiveness. The principal problem with existing trenches at Way Kambas is where streams or wetlands flood and erode the trenches, enabling elephants to cross. The development of a more robust drainage network and concrete supports is required to strengthen these areas. Even without additional structures, existing trenches reduce the number of available entry points for elephants and enable villagers to concentrate their guarding efforts at fewer locations.

Santiapillai \& Widodo (1989) recommend the establishment of elephant control teams, which would be a visible and strong symbol of the government's support. Nothing was enacted and the need for these teams remains. One way to support village-level activities would be to provide villages with lights, radios and other appropriate technology to defray the cost of guarding their fields. Chemical deterrents such as pepper spray have been suggested as another method to deter elephants (Seidensticker, 1984; Santiapillai \& Suprahman, 1986). Considering the relative seriousness of the issue, the efficacy and cost-effectiveness of pepper spray should be evaluated.

When significant damage or loss of life occurs, villagers argue that they deserve compensation for bearing the brunt of the cost associated with having large elephant populations near densely populated areas. At present, there is no regular system of compensation for crop loss or human injury or death at Way Kambas. Some compensation is provided to the families of villagers who are killed, although it is perceived by villagers to be inadequate. In one village, 40 people reportedly each received one can of cooking oil and five cartons of instant noodles in response to elephant damage. Villagers frequently discussed the injustice of receiving little remuneration should they be injured or killed by an elephant, while facing stiff jail terms and fines if they hurt elephants. An adequate compensation fund would likely provide at least a morale boost to the 'front lines' of villagers facing elephant raids on an almost daily basis.

\section{Impact of crop raiding and implications for conservation}

Villagers near the park border are under near constant assault by elephants in some areas. Crops are destroyed, buildings are damaged, people are injured and killed, and considerable time, resources and money are spent to mitigate these conflicts. Some villagers plant less valuable crops, such as cassava or grasses, near the border to reduce the risk of damage to high-value crops, such as rice. Other villagers plant or harvest crops at non-optimal times to reduce the risk of losing all in one night of crop raiding. Under these conditions, it is difficult to expect these villagers to have positive attitudes towards elephants, the park or conservation authorities. These negative attitudes can result in villagers responding to conflict with violence, such as when elephants are killed by villagers. Retaliation 
against elephants for crop raiding is an important, but rarely discussed, threat to the long-term future of elephants in Sumatra. In 1997, for example, 12 elephants were poisoned by workers at an oil palm plantation (Suara Pembaruan, 7 March 1997).

In the next decades, efforts to save the elephant and its habitat may be won or lost in the battle for public perception. The Asian elephant holds a unique place in the history, religion and folklore of Asia (Santiapillai \& Jackson, 1990) and its cultural significance makes it a potentially important umbrella and flagship species in efforts to conserve Asia's dwindling forests. Conversely, conflict between elephants and people may act instead as lighting rods that increase negative attitudes towards conservation, and hinder efforts to save these same species and protected areas.

In Sumatra, the translocation and training of elephants has been a principal management strategy to control problem elephants. Elephants moved to one of the island's six ETCs (Lair, 1997) were intended to be used productively in logging or other economically viable activities (McNeely, 1978; Santiapillai \& Widodo, 1993a). Between 1986 and the end of 1995, 520 elephants were captured and moved to an ETC and Indonesian authorities have a goal to capture 900 elephants by the year 2001 (Lair, 1997). At Way Kambas, the considerable growth in the number of elephants at the ETC, an increase from 69 in 1993 to over 160 in 1998 (Rusman, Director of ETC, pers. comm.), is costly to maintain. The large number of elephants, a severe drought and the country's economic crisis have resulted in sharply higher costs for food and medication. The training of elephants, many of the captured 'problem elephants', was never intended to be a long-term solution to the elephant problem (Santiapillai \& Widodo, 1993a). To date, the market for elephants for industrial applications, such as logging, has not emerged and the market for elephants as tourist or circus animals is relatively small. In 1992 and 1994, reports of a possible elephant cull, endorsed by the Ministry of Transmigration, resulted in an international outcry and the cancellation of the plan (Lair, 1997). Some consideration of population management may be necessary once elephants begin exceeding their carrying capacity at protected areas like Way Kambas, but culling has not proven an effective tool in reducing crop damage in African sites (L. Naughton-Treves, pers. comm.) and even a lone bull elephant in the forest has the potential to raid crops (Sukumar, 1989).

\section{Conclusion}

In Sumatra, as human population growth continues to increase and elephant habitat continues to decrease, successful elephant conservation will increasingly be measured in terms of how well people and elephants can be kept separated. People and elephants will never be happy neighbours as long as elephants damage crops, infrastructure, and injure or kill people. This study shows that crop raiding at Way Kambas occurs year-round, subjecting farmers in these villages to near constant pressure. Few strategies to control damage caused by elephants are entirely effective, but there may be an important role for trenches, grassland buffers and rivers as boundaries to separate elephants and cultivated areas in Sumatra in addition to the capture of habitual crop raiders, use of elephant control teams, assistance to villagers guarding crops, compensation and chemical deterrents (Table 3). At Way Kambas National Park, additional efforts such as elephant control teams, electric fences, chemical deterrents and compensation should be considered.

\section{Acknowledgements}

We are grateful to our sponsors and counterparts in Indonesia: The Indonesian Institute of Sciences, the Ministry of Forestry's Directorate of Forest Protection and Nature Conservation, Taman Safari Indonesia, the director and staff of Way Kambas National Park, staff and students of the University of Lampung, and staff of the Sumatran Tiger Project. We especially acknowledge the assistance of local community leaders and informants. This study was funded primarily by the Save The Tiger Fund, a special project of the National Fish and Wildlife Foundation in partnership with ExxonMobil, administered through the Minnesota Zoo Foundation. Additional support was received from The Rhinoceros and Tiger Conservation Fund of the US Fish and Wildlife Service and the US National Security and Education Program (to P.N.). Other conservation partners of this component of the Sumatran Tiger Project include The Tiger Foundation (Canada), South Lakes Wild Animal Park (UK) and Dreamworld (Australia). Their generous support is gratefully acknowledged. Software was provided by ESRI, Inc. and ERDAS, Inc. Neil Franklin and Ben Drake assisted with the GIS map. Gail Carlson, Lisa NaughtonTreves, Steve Osofsky, Charles Santiapillai and an anonymous reviewer provided helpful comments on earlier drafts of the manuscript. 


\section{References}

Blouch, R.A. \& Haryanto (1984) Elephants in Southern Sumatri. Report 3. World Wildlife Fund, Bogor, Indonesia.

Blouch, R.A. \& Simbolon, K. (1985) Elcphants in Northern Sumatra. Report 9. World Wildlife Fund, Bogor.

Hill, C.M. (1998) Conflicting attitudes towards elephants around the Budongo Forest Reserve, Uganda. Encironnchtal Conservation, 25, 244-250.

Krishnamurthy, V. (1991) Recommendations for Improzing the Managenent of Captize Eleplants in Way Kambas National Park, Lampung Utara [sic]-Indonesia. WWF Project P3849: Sumatra, Way Kambas N.P. WWF Indonesia.

Lair, R. (1997) Gone Astray: The Care and Management of the Asian Elephant in Domesticity. FAO Regional Office for Asia and the Pacific, Bangkok, Thailand.

Marks, S.A. (1994) Local hunters and wildlife surveys: a design to enhance participation. African journal of Ecology, 32, 233-254.

McKay, G.M. (1973) Behavior and Ecology of the Asiatic Elephant in Southeastern Ceylon, Smithsonian Contribution to Zoology 125. Smithsonian Institution Press, Washington, DC.

McNeely, J.A. (1978) Management of elephants in Southeast Asia. In Wildlifo Management in Southeast Asia, vol. 8 (eds J. McNeely, D.S. Rabor and E.A. Sumardja), pp. 219-225. Biotrop, Bogor, Indonesia.

Ministry of Forestry (1995) Way Kambas National Park Mamagement Plan: 1994-2019. Ministry of Forestry, Directorate General of Forest Protection and Nature Conservation, Bogor, Indonesia.

Mukhtar, A.S. \& Sumarna, Y. (1994) Pattern of feed and daily range behavior of elephant in Way Kambas Nature Reserve, Lampung Province. Buletin Penclitian Hutan, 558, 1-13.

Nash, S.V. \& Nash, A.D. (1986) The elephants of Padang-Sugihan, Sumatra. Tigerpaper, 13, 28-29.

Naughton-Treves, L. (1998) Predicting patterns of crop damage by wildlife around Kibale National Park, Uganda. Conseruation Biology, 12, 156-168.

Newmark, W.D., Manyanza, D.N., Gamassa, D.G.M. \& Sariko, H.I. (1994) The conflict between wildlife and local people living adjacent to protected areas in Tanzania: human density as a predictor. Conservation Biology, 8, 249-255.

Nyhus, P.J. (1999) Elephants, tigers, and transmigrant: conflict and conseration at Way Kambas National Park, Sumatra, Indonesia. Unpublished PhD dissertation, University of Wisconsin, Madison.

Nyhus, P., Sumianto \& Tilson, R. (1999) The tiger human dimension in southeast Sumatra, Indonesia. In Riding the Tiger: Tiger Conservation in Human-dominated Landscapes (eds J. Seidensticker, S. Christie and P. Jackson). Cambridge University Press, Cambridge.

PHPA (1994) Strategi konservasi harimau Sumatera (Indonesian Sumatran Tiger Conservation Strategy). Direktorat Jenderal Perlindungan Hutan dan Pelestarian Alam, Departemen Kehutanan, Republik Indonesia, Jakarta, Indonesia.
Salter, R.E. (1986) Evaluation and monitoring of Asian elephant habitat: problems and some potential solutions. Tigerpaper, 13, 5-9.

Santiapillai, C. \& Jackson, P. (eds) (1990) The Asian Elephant: An Action Plan for its Conservation. IUCN/SSC Asian Elephant Specialist Group. IUCN, Gland.

Santiapillai, C. \& Suprahman, H. (1985) Habitat management in Way Kambas Game Reserve with reference to the elephant population (WWF/IUCN Project 3133-No. 2). Tigerpaper, 12, 20-27.

Santiapillai, C. \& Suprahman, H. (1986) The Ecology of the Elephant (Elephas maximus L.) in the Way Kambas Game Reserve, Sumatra. WWF/IUCN Final Report 3133. WWF/IUCN, Bogor.

Santiapillai, C. \& Widodo, R. (1989) Management of Elephant in Captivity in Riau, Sumatra. Report prepared for PHPA and WWF 3769. World Wide Fund for Nature, Bogor, Indonesia.

Santiapillai, C. \& Widodo, R. (1993a) Reconciling elephant conservation with economic development in Sumatra. Gajah, 10, 11-18.

Santiapillai, C. \& Widodo, R. (1993b) Why do elephants raid crops in Sumatra. Gajah, 11, 55-58.

Seidensticker, J. (1984) Managing Elephant Depredations in Agricultural and Forestry Projects. The World Bank, Washington, DC.

Senanayake, S. \& Kusumawardhani, L. (1986) Crop Depredation by Wild Elephants around the Way Kambas Game Reserve and Mitigative Measures. US AID Training Mission; The School of Environmental Management, Bogor; Directorate General of Forest Protection and Nature Conservation, Indonesia; and Department of Wildlife Conservation, Sri Lanka, Jakarta.

SPSS (1999) SPSS. SPSS, Inc., Chicago, IL.

Studsrød, J.E. \& Wegge, P. (1995) Park-people relationships: the case of damage caused by park animals around the Royal Bardia National Park, Nepal. Environmental Conservation, 22, 133-142.

Stüwe, M., Agdul, J.B., Nor, B.M. \& Wemmer, C.M. (1998) Tracking the movements of translocated elephants in Malaysia using satellite telemetry. Oryx, 32, 68-74.

Sukumar, R. (1989) The Asian Elephant: Ecology and Management. Cambridge University Press, Cambridge.

Thouless, C.R. \& Sakwa, J. (1995) Shocking elephants: fences and crop raiders in Laikipia district, Kenya. Biological Conservation, 72, 99-107.

Tilson, R., Soemarna, K., Widodo, R., Sukumar, R., Seal, U., Traylor-Holzer, K. \& Santiapillai, C. (eds) (1994) Asian Elephant in Sumatra: Population and Habitat Viability Analysis Report. IUCN/SSC Conservation Breeding Specialist Group, Apple Valley, MN.

Widjaja, T.M., Iswari, A. \& Syafii, H. (1986) Management strategy for the Sumatran elephant (Elephas maximus sumatranus) in Way Kambas Game Reserve. In The Conservation and Management of Endangered Plants and Animals (eds C. Santiapillai and K. Ashby). Bogor Indonesia. 


\section{Biographical sketches}

Philip Nyhus is a US National Science Foundation postdoctoral fellow in Environmental Studies at Colby College, Maine (USA). He received his $\mathrm{PhD}$ from the University of Wisconsin (USA) and has been associated with the Sumatran Tiger Project since 1995.

Sumianto is a graduate of the University of Lampung (Indonesia) and coordinates the Sumatran Tiger Project's Community Conservation and Education Program in Sumatra. He grew up in a village bordering Way Kambas National Park and has extensive first-hand experience with crop-raiding elephants.

Ronald Tilson is Director of Conservation at the Minnesota Zoo (USA), Director of the Sumatran Tiger Project, and Director of the Tiger Information Center (www.5tigers.org). He coordinates the Tiger Global Conservation Strategy, a programme of the IUCN/SSC Conservation Breeding Specialist Group, and chairs the board of directors of The Tiger Foundation (Canada). 